\title{
A terminal level analysis of service quality at Nigerian seaports
}

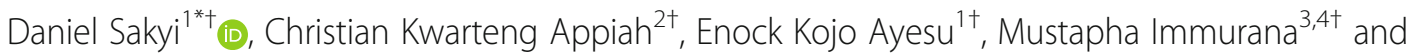 \\ Samuel Tawiah Baidoo ${ }^{1+}$
}

*Correspondence: dsakyi2003@ yahoo.com; dsakyi.cass@knust.edu. gh

${ }^{1}$ Department of Economics, Kwame Nkrumah University of Science and Technology (KNUST), Private Mail Bag, Kumasi, Ghana

Full list of author information is available at the end of the article

\begin{abstract}
Seaport terminals are major facilitators of international trade. One issue that is very crucial to the performance and survival of seaport terminals is the quality of service provided. However, in order to enhance the quality of service provided at these terminals, it is important to know customers' expectations and perceptions about service quality. Notwithstanding, very little is known about customers' expectations and perceptions on the service quality of seaport terminals in Africa. This paper therefore provides a comparative analysis of service quality of Nigerian seaport terminals with the aid of the gap score technique of the service quality (SERVQUAL) model. It is found that generally, all the selected terminals studied have low service quality. With regard to the average gap score per service quality dimension for all the selected terminals, transparency has the best service quality (least gap score) whiles responsiveness has the least service quality (highest gap score). The implication is that, in seaport terminals quest to enhance service quality, more attention should be paid towards enhancing responsiveness by providing prompt services, helping customers and informing them when exactly services will be performed.
\end{abstract}

Keywords: Trade facilitation, Service quality, Seaport terminals competitiveness, Nigeria JEL classification: F10, L25, M11

\section{Introduction}

Improved service quality remains an important part of the agenda of profit-oriented firms because it is essential in granting firms a competitive advantage, more so in the wake of intense competition among firms in recent times. Further, literature (see: Hemalatha et al. 2018; Ismail et al. 2006; Kolanović et al. 2011; Regasa 2016), shows that there are potential advantages of improved service quality to firms and the world economy at large. Among the immediate benefits to firms is improved demand for services. Hence knowing customers expectation and perception about quality of the services provided cannot be overemphasised.

The above implies that, for firms to remain in business via enhanced customer satisfaction, ensuring better service quality is inevitable. Notwithstanding, firms must know how customers value the services provided, in order to enhance service quality. Knowing this would help firms focus on areas of services that directly affect their competitive advantage

(c) The Author(s). 2020 Open Access This article is licensed under a Creative Commons Attribution 4.0 International License, which permits use, sharing, adaptation, distribution and reproduction in any medium or format, as long as you give appropriate credit to the original author(s) and the source, provide a link to the Creative Commons licence, and indicate if changes were made. The images or other third party material in this article are included in the article's Creative Commons licence, unless indicated otherwise in a credit line to the material. If material is not included in the article's Creative Commons licence and your intended use is not permitted by statutory regulation or exceeds the permitted use, you will need to obtain permission directly from the copyright holder. To view a copy of this licence, visit http://creativecommons.org/licenses/by/4.0/. 
and also to oust wastage of resources in less important areas (Suuroja 2003; Ghotbabadi et al. 2012). Thus, assessing service quality helps stakeholders to know how to adopt and implement measures to improve the quality of services customers receive (Ghotbabadi et al. 2012).

With reference to firms, seaport terminals ${ }^{1}$ are major facilitators of international trade globally. For Africa, over $90 \%$ of the continents' exports and imports are done through the sea and hence improving the quality of services provided by seaports and their terminals is non-negotiable (African Ports Evolution 2016). Moreover, given that international trade if effectively facilitated is vital for economic and social welfare outcomes in Africa (see for example, Hoekman and Shepherd 2015; Sakyi et al. 2017; Sakyi et al. 2018), enhancing the quality of services provided at African seaport terminals remain very essential. Notwithstanding, most African seaports and their terminals are bedevilled with challenges that result in delays, inefficiency and low service quality leading to the marginalisation of Africa in the global market (Chikere et al. 2014; African Development Bank's first Transport Forum 2015; Abdourahamane 2015).

It is interesting to note that, although some studies about customers' expectations and perceptions about service quality of seaports have been conducted, globally, very little is known (see Lu et al. 2011; Sayareh et al. 2016; Hemalatha et al. 2018) about terminal level analyses of service quality provided by seaports. ${ }^{2}$ On African seaports (see for example, Ugboma et al. 2004; Ugboma et al. 2007; Onyemechi et al. 2017), to the best of our knowledge, virtually no study has provided a terminal level analysis of service quality like the one proposed in this paper. We argue that, doing a terminal level analysis is more revealing since a seaport may be having performing and nonperforming terminals. Therefore, doing a whole seaport analysis may not reveal which terminals are having low service quality and, hence needing urgent attention. Consequently, this paper which is devoted to seaport terminals in Nigeria contributes immensely to the body of knowledge by making at least two important contributions; (i) it is the first to provide a terminal level analysis of service quality at African seaports, (ii) it highlights terminals that need the most attention in the quest to improve service quality among Nigerian seaports. Last but not the least, the results of the study are more general with wider applicability because of the usage of at least 500 seaport terminals customers which to the best of authors' knowledge, no study (even those on other continents) has considered.

The remainder of the paper is structured as follows. The next section covers literature review. The third section outlines the methodology adopted by the study. The fourth section is dedicated to the empirical results and discussion, whiles the final section covers the conclusion and policy suggestions.

\section{Literature review}

In contemporary literature, service quality remains important because it can influence customer satisfaction, which may in turn affect customer loyalty. Thus, improved service quality can increase the likelihood of customer satisfaction and the need for a customer to patronise the services of a particular firm most of the times and vice versa

\footnotetext{
${ }^{1}$ A seaport terminal is a man-made facility at seaport with space for handling containers for on-loading and off-loading of goods. They are usually operated under the control of seaport authority or third party.

${ }^{2}$ Most of the few studies on terminal level analyses are found in Asia.
} 
(Chang and Thai 2016). However, while customer satisfaction may not always translate into customer loyalty, the fact that customers are loyal means they are definitely satisfied (Ghotbabadi et al. 2012). Notwithstanding, the postulation of Ghotbabadi et al. (2012) that customer loyalty implies customer satisfaction is likely not to happen in situations where due to family ties and monopoly among others, customers may portray loyalty even though they are not satisfied.

According to Ghotbabadi et al. (2012), the four most relevant models for service quality evaluations are the Hierarchical model, Multilevel model, SERVQUAL model, and the Nordic model. The Hierarchical model attributable to Brady and Cronin (2001) has three main dimensions: interaction quality (behaviour, expertise and attitude), physical environment quality (social factors, ambient conditions and design), and outcome quality (tangibles, valence and waiting time), with each dimension having three sub-dimensions as shown in parentheses. The Multilevel model of Dabholkar et al. (1996) comprises of the overall service quality dimension, primary dimensions and subdimensions, making it a three-stage model of service quality. The SERVQUAL model by Parasuraman et al. (1988) measures the difference between the perception and expectation of customers regarding the quality of the service delivered using five main dimensions: responsiveness (prompt services, preparedness to help customers etc.), tangibility (equipment, physical facilities etc.), assurance (trust, confidence and courtesy of employees etc.), empathy (giving personal and individual attention to customers etc.) and reliability (providing services as promised among others). Grönroos (1984) is attributed with the Nordic model which has functional quality, image quality and technical qualities as its main dimensions. Functional quality entails the processes involved in the delivery of services, the image quality has to do with the reputation of the firm, while the technical quality has to do with what is delivered. Notwithstanding the above, according to Chang and Thai (2016), the SERVQUAL model is the most popular.

From a theoretical angle, service quality can be viewed from two perspectives: that of the customer and the perspective of the firm (Kolanović et al. 2011). Regarding the customers' perspective, service quality is viewed as the perception/ judgement of customers as to how they rate the services provided by a firm. Thus, under the customers' perspective, service quality is measured by rendering what meets the requirements of customers (Zeithaml 1988). As regards the firms' perspective, price is the main principal factor, hence as far as customers are prepared to pay, firms are also willing to offer services with commensurate level of quality. Thus, simply, the higher the price customers are prepared to pay, the higher the quality of the services firms are willing to render (Kolanović et al. 2011). Notwithstanding the above, this paper focuses on service quality from the customers' perspective.

Empirically, Ugboma et al. (2004) with a sample of 40 port users, examine the quality of services provided at Port Harcourt and Lagos seaports in Nigeria using the SERVQUAL technique. The study finds that port users rated the services of Port Harcourt Port higher than that of Lagos Port. Notwithstanding, with respect to both ports, while port users rate tangibility and responsiveness dimensions higher, lower ratings are offered with respect to the empathy dimension. Similarly, Ugboma et al. (2007) employing the SERVQUAL model and customer satisfaction index, investigate service quality among Lagos and Port Harcourt seaports in Nigeria. The study uses a sample of 40 clearing 
agents as respondents. The findings show that, Port of Port Harcourt has better services than Port of Lagos, with tangibility found to be the least essential driver of service quality at the two ports.

In a related study, Kolanović et al. (2011) in Croatia, assess the quality of service at Rijeka Port using a sample of 142 port users while employing the principal component factor analysis as the estimation technique. The study uses port reliability factor, port information availability factor, port functionality factor, port flexibility factor and port accessibility factor as service quality dimensions. It is found that port accessibility factor and port reliability factor are the first and second most important factors that affect service quality respectively. Moreover, port functionality factor, port information availability and port flexibility factors are the third, fourth and fifth most important with regard to service quality, respectively. Further, Lee and $\mathrm{Hu}$ (2012) examine service quality among ports of Shanghai, Singapore, Hong Kong, Kaohsiung and Busan with the aid of 25 port users as well as the Importance-Performance Analysis (IPA) technique. In all, Port of Singapore is found to provide better services as compared to the other ports whilst Port of Kaohsiung is found to be the worst performing port. Further, Port of Shanghai is revealed to have a low satisfaction as regards assurance and responsiveness relative to the other ports; notwithstanding, tangibility is rated to have a better satisfaction.

$\mathrm{Lu}$ et al. (2011) investigate the most important container terminal attributes in Shenzhen, China, by sampling 42 shipping agencies and shipping lines. The study uses factor analysis, internal-consistency reliability, and cluster analysis among others as estimation techniques. The findings show that reliability of vessel sailing time is viewed by the respondents as the most important attribute. This is followed by the efficiency of custom declaration, the efficiency of loading and discharging, port cost and the availability of berth in that order.

Similarly, Yeo et al. (2015) in Korea using a sample of 99 port users of 28 container ports, investigate service quality and customer satisfaction employing the partial least squares structural equation modelling as the estimation technique. The results show ports service quality to have five-dimensional construct made of items linked to resources, management, process, social responsibility and image/reputation, and outcomes. Moreover, the management and the social responsibility and image related factors, are found to have the greatest influence on customer satisfaction.

Thai (2016), at the Port of Singapore, contributes to the subject matter by examining the relationship between customer satisfaction and port service quality using a sample of 175 port users- cargo owners, shipping lines, logistics service providers and freight forwarders by employing multiple regression and confirmatory factor analysis techniques. The author finds that, outcome, process and image/reputation, social responsibility and management are the main port service quality dimensions and all these dimensions are found to have positive significant relationships with customer satisfaction. However, outcomes-related port service quality factor is found to be the dimension with the greatest effect. Sayareh et al. (2016) in Iran, evaluates service quality at the Shahid Rajaee Container Terminal in Bandar Abbas Port (made of 9 different terminals) using a sample of 127 port users while employing the SERVQUAL model, the Technique of Order Preference Similarity to the Ideal Solution (TOPSIS) and the t-test as estimation techniques. All the five 
service quality dimensions of the SERQUAL model are considered in this study. The findings show that in all the five dimensions, there are significant gaps between customers' expectations and perceptions with the empathy and tangibility dimensions having minimum and maximum gaps respectively. Moreover, tangibility, reliability, assurance, responsiveness and empathy are found to be the most important dimensions to service quality in order of ranking respectively.

Chang and Thai (2016) in Taiwan, at the Port of Kaohsiung, investigate the relationships between port security quality, customer loyalty, customer satisfaction and port service quality using a sample of 104 managers of shipping companies and freight forwarders. Factor analysis, the least square regression technique and descriptive statistics are used as data analyses techniques. High level of operational efficiency, speedy service and response to requirements of customers, availability of facilities and equipment, are found to be the most essential factors that affect service quality at Port of Kaohsiung. Moreover, reliability of port services, overall service quality and reputation of the port are the important attributes as regards customer loyalty and satisfaction. Further findings also show that port service quality significantly affects customer loyalty and satisfaction positively.

Onyemechi et al. (2017) in Nigeria, investigates the quality of the services rendered by seaports in the Eastern and Western port zones by employing factor analysis and the SERVQUAL model. The study uses 223 port users as respondents. The findings show that good access to the terminal and modern cargo handling equipment are the significant attributes under tangibility dimension. Under the reliability dimension, delivery on promise, standard cargo discharge procedure and time efficiency are the significant attributes. In addition, as regards the assurance dimension, the results show that effective security at port, well skilled workers, effective handling of complaints and minimal cargo damage are the significant attributes. Also, under the empathy dimension, giving attention to customers, provision of value-added service, prompt information of problems and provision of after delivery services are the significant attributes. Concerning the responsiveness dimension, effective government/private agencies corporation and responsive settlement of claims are revealed as the significant attributes.

Hemalatha et al. (2018) examine the service quality of twelve container terminals in India by sampling 25 respondents (customers). The estimation techniques used are the SERVQUAL model and TOPSIS among others. The study finds the tangibility dimension to be the most important followed by the reliability, assurance, responsiveness, and empathy dimensions in that order.

From all the above studies, it can be seen that, while most of them focus on the analysis of service quality of seaports as a whole, very few of them (Lu et al. 2011; Sayareh et al. 2016; Hemalatha et al. 2018) are on the service quality of terminals. However, among those that focus on terminals, all of them are conducted in Asia. Moreover, unlike a whole port analysis, a terminal level analysis has the greatest potential of revealing performing and non-performing terminals, hence giving port managers an idea of which terminals to be focused on in order to enhance the service quality of a particular seaport. This study therefore fills a lacuna in literature by being the first, to the best our knowledge, to investigate the service quality of seaport terminals in Africa, using Nigeria as the setting. 
Methodology

\section{Questionnaire design}

The study employs primary data. The data is obtained using a structured questionnaire on customers' expectation and perception about the quality of the services provided at terminals of Port of Apapa and Tincan Island Port in Nigeria. Respondents who could read, understand and write in English (language used in designing the questionnaire) fill the questionnaire by themselves and for those who could not read, understand and write in English, the questions are interpreted to them in the language they understand and the responses are used to fill the questionnaire accordingly. The questionnaire (see Appendix A) entails four sections. The first section (section A) covers questions on tangibility, responsiveness, reliability, empathy and assurance dimensions of service quality. Questions on transparency indicators are captured in the second section (section B) while questions on average shipping time, cost to import/export and procedural and documentation requirements are captured in section $C$. In the last section, the challenges faced by port users when importing and exporting are captured. The terminals used are ENCL Consortium Ltd. (ENLC), Apapa Bulk Terminal (ABT), AP Moller Terminal (APMT), Five Star Logistics Ltd. (FSLT), Tincan Island Container Terminal (TICT), Ports and Cargo Handling Service Ltd. (PCHS), Josepdam Port Services (JPS) and Ports and Terminal Multi-Service Ltd. (PTML). Agents, exporters, importers, shipping lines and freight forwarders are the customers of these terminals considered in this study.

\section{Sampling technique}

A two-stage sampling technique is employed. Convenient sampling technique is used to choose the selected seaports in the first stage whilst in the second stage, the simple random sampling technique is used to select customers found at terminals of the selected seaports. Employing the simple random sampling technique gives every customer the chance of being selected. Extra information on sampled customers are summarised in Table 1.

Table 1 Summary of data

\begin{tabular}{ll}
\hline Seaport terminals & $\begin{array}{l}\text { Number of respondents } \\
\text { (Customers) }\end{array}$ \\
\hline ENLC LTD (Consortium) & 70 \\
ABT & 61 \\
APMT & 75 \\
FSLT & 65 \\
TICT & 70 \\
PCHS & 70 \\
IPS & 65 \\
PTML & 65 \\
Total & 73 \\
\hline
\end{tabular}




\section{Methods}

The study uses the Service Quality (SERVQUAL) model proposed by Parasuraman et al. $(1985,1988)$ to measure service quality among selected seaport terminals in Nigeria. SERVQUAL-is the actual quality of the service received (perception) minus customers' expectation of service quality (expectation) (Gronroos 1982; Parasuraman et al. 1988). This methodology has been used widely in service quality studies (Chang and Thai 2016) and it measures the quality of services provided by firms under the following dimensions (see Parasuraman et al. 1988): i) tangibles- this dimension covers the tangible aspect of service delivery and includes items such as the equipment of the firm, physical setup and staff appearance among others, ii) reliability- it covers the extent of reliability of service providers and hence how service is rendered on time and as promised, iii) responsivenessthis covers willingness to serve customers as well as the provision of prompt services, iv) assurance- this measures meeting the needs of customers on time and as promised and thus conveying confidence and trust, and v) empathy- this covers how customers want service providers to care and feel about them among others. The SERQUAL model is chosen because of its general use which aids in comparing service quality among firms in the same industry. Moreover, it is regarded as the best way to reliably and faithfully examine the expectation of customers as well as the level of quality of services rendered. Thus, it helps in revealing the extent of fulfilment of the expectations of customers thereby revealing the greatest challenges confronting service quality. This therefore helps firms in choosing the most effective ways toward enhancing customer satisfaction (Stverkova 2015). Before the gap score analysis of the SERVQUAL, we use the one-way Analysis of Variance (ANOVA) to find out whether there are significant differences in the mean perception and expectation scores across the terminals. Moreover, we conduct extra terminal wise analyses using the Bonferroni approach to find out whether there exist significant differences in the mean perception and expectation scores across (between) the terminals.

In addition to the aforementioned dimensions, we add a sixth dimension known as transparency. This is because transparency (see for example Joshi 2013; Douglas and Meijer 2016) can enhance the image of an organisation via service quality. Also, we add the transparency dimension because compared to other regions of the world operations at African seaport terminals, are often perceived not to be transparent. In this paper therefore, transparency deals with the availability of trade related information, bribery and corruption and equity in relating to customers among others. The Likert-type scale (1- Strongly disagree; 2- Disagree; 3- Satisfactory; 4- Agree; and 5- Strongly agree are used for all questions with the exception of 'willing to give extra money to influence seaports officials' and 'deliberately extorting money from customers' under the transparency dimension and 'busy to respond to customers' request promptly' under the responsiveness dimension where the scale is reversed as 1 - Strongly agree; 2- Agree; 3- Satisfactory; 4- Disagree; 5- Strongly disagree; since the questions are framed in the negative sense) is employed in designing the responses under the SERVQUAL instrument. By way of estimation strategy, the service quality gap score - perception score minus expectation score - is used. According to Parasuraman et al. (1988), the perceived satisfaction a customer expects from a firm is referred to as customer's expectation while the actual satisfaction a customer derives from a firm's services is termed as customer's satisfaction. Thus, service quality is considered high (low) if customers' expectations (perceptions) are lesser than their perceptions (expectations) of 
Table 2 One-way ANOVA results for perception scores

\begin{tabular}{llllll}
\hline Source & SS & df & MS & F & Prob > F \\
\hline Between groups & 45.96 & 7 & 6.57 & 44.48 & 0.0000 \\
Within groups & 79.85 & 541 & 0.15 & & \\
Total & 125.80 & 548 & 0.23 & & \\
\hline
\end{tabular}

Source: Authors

a service provided. According to Parasuraman et al. (1988), a positive score indicates higher service quality and hence customer satisfaction.

Last but not the least, in order to ensure the efficiency and statistical appropriateness of the results, we employ the Cronbach's alpha proposed by Cronbach (1951) to test the reliability of the instrument used for the data collection. The reliability test shows the internal consistency among items (questions) on the questionnaire. The higher the Cronbach's alpha value, the more the appropriateness of the instrument used and hence according to Field (2009), a reliable instrument should have an alpha value of 0.7 and above.

\section{Results and discussion}

Here, the paper provides a thorough analysis of service quality across the selected terminals stated in section 3. Also, key challenges confronting importation and exportation at these terminals are revealed.

\section{Analyses of mean difference in perception and expectation scores across terminals}

In this subsection, we use the one-way ANOVA to find out whether there exist significant differences in the mean perception and expectation scores across the terminals. The findings show that there exists statistically significant differences in the mean perception and expectation scores of the selected terminals, since the $p$-values are all less than 0.01 (see Tables 2 and 3). This clearly shows that, customer's expectations and perceptions as regards service quality among these terminals significantly differ.

Further, terminal wise analyses of mean perception and expectation scores (see Appendix B) is also done in order to find out which terminals perception and expectation scores are significantly different and otherwise.

\section{Analyses of service quality questions and dimension scores across terminals}

This subsection presents the expectations and perceptions of seaport customers with reference to various questions under the service quality dimensions. As earlier indicated, this paper uses a 5-point Likert scale for the service quality questions in order to assess the expectation and perception of customers regarding the quality of services rendered at the selected terminals.

We report in Tables 4, 5, 6, 7, 8, 9 and 10 the expectation and perception scores of customers concerning services offered at the selected terminals under the tangibility,

Table 3 One-way ANOVA results for expectation scores

\begin{tabular}{llllll}
\hline Source & SS & df MS & MS & F & Prob > F \\
\hline Between groups & 0.98 & 7 & 0.14 & 11.02 & 0.0000 \\
Within groups & 6.89 & 541 & 0.01 & & \\
Total & 7.87 & 548 & 0.01 & & \\
\hline
\end{tabular}

Source: Authors 
Table 4 Service quality expectation and perception average scores for tangibility

\begin{tabular}{|c|c|c|c|c|c|c|c|c|}
\hline Service quality questions & ENLC & $\mathrm{ABT}$ & APMT & FSLT & $\mathrm{TICT}$ & PCHS & JPS & PTML \\
\hline \multicolumn{9}{|l|}{ Expectation dimension } \\
\hline Up-to-date equipment & 5 & 5 & 4.71 & 5 & 5 & 4.97 & 4.98 & 5 \\
\hline Physical facilities are visually appealing & 5 & 5 & 4.75 & 5 & 5 & 4.97 & 5 & 4.97 \\
\hline Staff are well-dressed and neat & 4.94 & 5 & 5 & 5 & 5 & 5 & 5 & 5 \\
\hline $\begin{array}{l}\text { Appearance of physical facilities are in line } \\
\text { with the type of services provided }\end{array}$ & 5 & 4.95 & 5 & 5 & 4.97 & 4.94 & 5 & 4.96 \\
\hline Expectation scores & 4.99 & 4.99 & 4.87 & 5 & 4.99 & 4.97 & 5 & 4.98 \\
\hline \multicolumn{9}{|l|}{ Perception dimension } \\
\hline Up-to-date equipment & 4.07 & 4 & 4.16 & 2.37 & 4.09 & 3.71 & 4.05 & 4.27 \\
\hline Physical facilities are visually appealing & 3.23 & 3.64 & 3.8 & 2.35 & 3.87 & 3.47 & 3.72 & 3.99 \\
\hline Staff are well-dressed and neat & 4.07 & 4.02 & 4.39 & 3.46 & 4.24 & 4 & 4.12 & 4.47 \\
\hline $\begin{array}{l}\text { Appearance of physical facilities are in line } \\
\text { with the type of services provided }\end{array}$ & 3.43 & 3.84 & 3.44 & 2.97 & 3.74 & 3.77 & 3.83 & 4.23 \\
\hline Perception scores & 3.7 & 3.88 & 3.95 & 2.79 & 3.99 & 3.74 & 3.93 & 4.24 \\
\hline \multicolumn{9}{|l|}{ Gap scores } \\
\hline Up-to-date equipment & -0.93 & -1 & -0.55 & -2.63 & -0.91 & -1.26 & -0.93 & -0.73 \\
\hline Physical facilities are visually appealing & -1.77 & -1.36 & -0.95 & -2.65 & -1.13 & -1.5 & -1.28 & -0.98 \\
\hline Staff are well-dressed and neat & -0.87 & -0.98 & -0.61 & -1.54 & -0.76 & -1 & -0.88 & -0.53 \\
\hline $\begin{array}{l}\text { Appearance of physical facilities are in line } \\
\text { with the type of services provided }\end{array}$ & -1.57 & -1.11 & -1.56 & -2.03 & -1.23 & -1.17 & -1.17 & -0.73 \\
\hline Gap scores & -1.29 & -1.11 & -0.92 & -2.21 & -1.01 & -1.23 & -1.07 & -0.74 \\
\hline
\end{tabular}

responsiveness, reliability, empathy, assurance, and transparency service quality dimensions. Also, gap scores linked to questions under these dimensions are presented. The expectation scores indicate how customers want services to be offered whilst perception scores indicate how customers perceive the actual quality of service rendered. Thus, the lower the expectation (perception) score, the lower the expectation of customers (quality of service received). Also, and as earlier indicated, the gap score is the difference between perception score and expectation score.

Regarding the tangibility dimension (Table 4) concerning the use of up-to-date equipment, the results show clearly that, all expectation scores are higher than perception scores by customers which results in negative service quality gap scores of -0.93 for ENLC, -1 for ABT, -0.55 for APMT, -2.63 for FSLT, -0.91 for TICT, -1.26 for PCHS, -0.93 for JPS and -0.73 for PTML. Thus, under the tangibility dimension, APMT ranks highest on the use of up-to-date equipment, followed by PTML, TICT, ENLC and JPS, ABT, PCHS and FSLT in that order. Sayareh et al. (2016) report similar finding for some selected ports in Iran. The scores for the remaining expectation and perception questions under the tangibility dimension are reported in Table $4 .^{3}$

Concerning the average gap scores under the tangibility dimension, it can be seen that, the expectation scores are greater than all the perception scores which leads to negative gap scores of -1.29 for ENLC, -1.11 for ABT, -0.92 for APMT, -2.21 for FSLT, -1.01 for TICT, -1.23 for PCHS, -1.07 for JPS and -0.74 for PTML. This outcome implies that, PTML ranks highest under the tangibility dimension, followed by APMT, TICT, JPS,

${ }^{3} \mathrm{We}$ do not discuss results related to more than one questions under all dimensions for the sake of brevity 
Table $\mathbf{5}$ Service quality expectation and perception average scores for reliability

\begin{tabular}{lllllllll}
\hline Service quality questions & ENLC & ABT & APMT & FSLT & TICT & PCHS & JPS & PTML \\
\hline Expectation dimension & & & & & & & & \\
Promises are honoured by the time given & 4.99 & 5 & 5 & 5 & 5 & 4.94 & 5 & 5 \\
Employees are concerned and supportive & 4.97 & 5 & 4.96 & 5 & 5 & 4.96 & 4.97 & 5 \\
Service providers are dependable & 4.96 & 5 & 5 & 4.98 & 5 & 4.97 & 5 & 5 \\
Fast and efficient services as promised & 4.97 & 4.98 & 4.99 & 4.91 & 4.94 & 4.96 & 5 & 5 \\
Keeping records accurately & 4.91 & 5 & 4.99 & 5 & 4.97 & 4.99 & 4.94 & 4.99 \\
Expectation scores & $\mathbf{4 . 9 6}$ & $\mathbf{5}$ & $\mathbf{4 . 9 9}$ & $\mathbf{4 . 9 8}$ & $\mathbf{4 . 9 8}$ & $\mathbf{4 . 9 6}$ & $\mathbf{4 . 9 8}$ & $\mathbf{5}$ \\
Perception dimension & & & & & & & & \\
Promise are honoured by the time given & 3.51 & 3.56 & 3.65 & 3.17 & 3.29 & 2.99 & 4.09 & 4.08 \\
Employees are concerned and supportive & 3.59 & 3.85 & 3.49 & 2.95 & 3.09 & 3.13 & 3.57 & 4.36 \\
Service providers are dependable & 3.83 & 3.7 & 4.08 & 2.72 & 3.27 & 3.3 & 4.46 & 4.12 \\
Fast and efficient services as promised & 3.63 & 3.62 & 4.25 & 2.68 & 2.71 & 2.81 & 4.22 & 3.9 \\
Keeping records accurately & 4.36 & 4.52 & 4.31 & 3.37 & 4.29 & 4.03 & 4.52 & 4.62 \\
Perception scores & $\mathbf{3 . 7 8}$ & $\mathbf{3 . 8 5}$ & $\mathbf{3 . 9 6}$ & $\mathbf{2 . 9 8}$ & $\mathbf{3 . 3 3}$ & $\mathbf{3 . 2 5}$ & $\mathbf{4 . 1 7}$ & $\mathbf{4 . 2 2}$ \\
Gap scores & & & & & & & & \\
Promise are honoured by the time given & -1.48 & -1.44 & -1.35 & -1.83 & -1.71 & -1.95 & -0.91 & -0.92 \\
Employees are concerned and supportive & -1.38 & -1.15 & -1.47 & -2.05 & -1.91 & -1.83 & -1.4 & -0.64 \\
Service providers are dependable & -1.13 & -1.3 & -0.92 & -2.26 & -1.73 & -1.67 & -0.54 & -0.88 \\
Fast and efficient services as promised & -1.34 & -1.36 & -0.74 & -2.23 & -2.23 & -2.15 & -0.78 & -1.1 \\
Keeping records accurately & -0.55 & -0.48 & -0.68 & -1.63 & -0.68 & -0.96 & -0.42 & -0.37 \\
Gap scores & $-\mathbf{1 . 1 8}$ & $-\mathbf{1 . 1 5}$ & $-\mathbf{1 . 0 3}$ & $-\mathbf{2}$ & $-\mathbf{1 . 6 5}$ & $-\mathbf{1 . 7 1}$ & $\mathbf{- 0 . 8 1}$ & $\mathbf{- 0 . 7 8}$ \\
\hline Source Authos & & & & & & & &
\end{tabular}

Source: Authors

$\mathrm{ABT}, \mathrm{PCHS}, \mathrm{ENLC}$ and FSLT in that order. These negative gap scores are not surprising since a major challenge to most seaport terminals in Africa is inadequate resources which hinders the acquisition of adequate up-to-date equipment to enhance service quality.

With reference to the reliability dimension (Table 5) concerning the question promises are honoured by the time given, it is evident that, all perception scores are lower than expectation scores which results in negative gap scores of - 1.48 for ENLC, -1.44 for ABT, -1.35 for APMT, -1.83 for FSLT, -1.71 for TICT, -1.95 for PCHS, -0.91 for JPS and -0.92 for PTML. Therefore, under the reliability dimension, JPS ranks highest regarding promises are honoured by the time given, followed by PTML, APMT, ABT, ENLC, TICT, FSLT and PCHS in that order. The scores for the other expectation and perception questions under the reliability dimension can be seen in Table 5 .

With regard to the average gap scores under the reliability dimension, from the results, since all the perception scores are below the expectation scores, it results in negative gap scores of -1.18 for ENLC, -1.15 for ABT, -1.03 for APMT, -2 for FSLT, -1.65 for TICT, -1.71 for PCHS, -0.81 for JPS and -0.78 for PTML. This suggests that, similar to tangibility, PTML ranks highest under the reliability dimension, followed by JPS, APMT, ABT, ENLC, TICT, PCHS and FSLT in that order. The implication of the finding is that, with regard to the provision of fast, efficient and dependable services, being supportive to customers when problem arises as well as keeping records accurately, the services provided by the selected Nigerian terminals do not meet the expectations of customers.

Under the responsiveness dimension (Table 6), concerning whether seaport officials tell customers exactly when services will be performed, negative gap scores of -1.06 for 
Table 6 Service quality expectation and perception average scores for responsiveness

\begin{tabular}{|c|c|c|c|c|c|c|c|c|}
\hline Service quality questions & ENLC & $\mathrm{ABT}$ & APMT & FSLT & $\mathrm{TICT}$ & PCHS & JPS & PTML \\
\hline \multicolumn{9}{|l|}{ Expectation dimension } \\
\hline $\begin{array}{l}\text { Tell customers exactly when services will } \\
\text { be performed }\end{array}$ & 4.99 & 4.98 & 5 & 5 & 5 & 4.94 & 5 & 5 \\
\hline Prompt services & 4.99 & 5 & 4.97 & 5 & 4.8 & 4.9 & 4.95 & 4.89 \\
\hline Willing to help customers & 4.94 & 4.93 & 4.97 & 4.97 & 4.91 & 4.89 & 4.94 & 4.84 \\
\hline $\begin{array}{l}\text { Busy to respond to customers' request } \\
\text { promptly }\end{array}$ & 4.86 & 5 & 4.97 & 4.97 & 4.86 & 4.49 & 4.34 & 4.9 \\
\hline Expectation scores & 4.95 & 4.98 & 4.98 & 4.99 & 4.89 & 4.81 & 4.81 & 4.91 \\
\hline \multicolumn{9}{|l|}{ Perception dimension } \\
\hline $\begin{array}{l}\text { Tell customers exactly when services will } \\
\text { be performed }\end{array}$ & 3.93 & 4 & 4.41 & 3.34 & 3.66 & 3.54 & 4.22 & 4.11 \\
\hline Prompt services & 3.63 & 3.64 & 4.41 & 2.6 & 2.76 & 2.93 & 3.72 & 3.95 \\
\hline Willing to help customers & 3.74 & 4.15 & 3.76 & 3.35 & 3.41 & 3.23 & 3.72 & 4.44 \\
\hline $\begin{array}{l}\text { Busy to respond to customers' request } \\
\text { promptly }\end{array}$ & 2.81 & 3.79 & 3.91 & 3.48 & 2.43 & 2.61 & 3.49 & 3.97 \\
\hline Perception scores & 3.53 & 3.9 & 4.12 & 3.19 & 3.07 & 3.08 & 3.79 & 4.12 \\
\hline \multicolumn{9}{|l|}{ Gap scores } \\
\hline $\begin{array}{l}\text { Tell customers exactly when services will } \\
\text { be performed }\end{array}$ & -1.06 & -0.98 & -0.59 & -1.66 & -1.34 & -1.4 & -0.78 & -0.89 \\
\hline Prompt services & -1.36 & -1.36 & -0.56 & -2.4 & -2.04 & -1.97 & -1.23 & -0.94 \\
\hline Willing to help customers & -1.2 & -0.78 & -1.21 & -1.62 & -1.5 & -1.66 & -1.22 & -0.4 \\
\hline $\begin{array}{l}\text { Busy to respond to customers' request } \\
\text { promptly }\end{array}$ & -2.05 & -1.21 & -1.06 & -1.49 & -2.43 & -1.88 & -0.85 & -0.93 \\
\hline Gap scores & $\overline{1.42}$ & -1.08 & $\overline{0} .86$ & $\overline{1.79}$ & -1.83 & $\overline{1.73}$ & -1.02 & $\overline{0.79}$ \\
\hline
\end{tabular}

Source: Authors

ENLC, -0.98 for ABT, -0.59 for APMT, -1.66 for FSLT, -1.34 for TICT, -1.4 for PCHS, -0.78 for JPS and -0.89 for PTML are obtained. Thus, regarding whether seaport officials tell customers exactly when services will be performed, APMT ranks highest followed by JPS, PTML, ABT, ENLC, TICT, PCHS and FSLT in that order. Moreover, apart from whether seaport officials are busy to respond to customers' request promptly, the scores for other questions under the responsiveness dimension follow similar explanation as the aforementioned ones.

Under the responsiveness dimension, the findings show negative gap scores of -1.42 for ENLC, -1.08 for ABT, -0.86 for APMT, -1.79 for FSLT, -1.83 for TICT, -1.73 for PCHS, -1.02 for JPS and -0.79 for PTML. Thus, PTML ranks highest under the responsiveness dimension, followed by APMT, JPS, ABT, ENLC, PCHS, FSLT and TICT in that order. These negative gap scores imply that customers' expectation with regard to getting prompt services and response to requests, receiving assistance from port staff and being informed on exactly when services will be performed are not met by the selected terminals.

With regard to the assurance dimension (Table 7), concerning officials being sympathetic and reassuring when problems arise, negative gap scores of -1.37 for ENLC, 1.17 for ABT, -0.88 for APMT, -1.35 for FSLT, -1.64 for TICT, -1.89 for PCHS, 0.98 for JPS and -0.65 for PTML are obtained. The implication is that concerning officials being sympathetic and reassuring when problems arise, PTML ranks highest followed by APMT, JPS, ABT, FSLT, ENLC, TICT and PCHS in that order. The 
Table 7 Service quality expectation and perception average scores for assurance

\begin{tabular}{|c|c|c|c|c|c|c|c|c|}
\hline Service quality questions & ENLC & $\mathrm{ABT}$ & APMT & FSLT & TICT & PCHS & JPS & PTML \\
\hline \multicolumn{9}{|l|}{ Expectation dimension } \\
\hline $\begin{array}{l}\text { Sympathetic and reassuring when } \\
\text { problems arise }\end{array}$ & 4.97 & 4.97 & 4.99 & 5 & 5 & 4.96 & 5 & 4.92 \\
\hline Trust officials at seaports & 4.99 & 4.98 & 4.84 & 4.98 & 5 & 4.97 & 4.98 & 4.95 \\
\hline $\begin{array}{l}\text { Feel safe in my transactions with } \\
\text { officials at seaports }\end{array}$ & 4.97 & 4.95 & 4.85 & 5 & 5 & 4.97 & 4.98 & 4.93 \\
\hline Seaports officials are polite & 5 & 4.97 & 4.71 & 5 & 4.97 & 4.97 & 4.95 & 4.97 \\
\hline $\begin{array}{l}\text { Officials get adequate support } \\
\text { from management }\end{array}$ & 4.99 & 4.97 & 4.95 & 5 & 4.94 & 4.96 & 4.92 & 4.95 \\
\hline Expectation scores & 4.98 & 4.97 & 4.87 & 5 & 4.98 & 4.97 & 4.97 & 4.94 \\
\hline \multicolumn{9}{|l|}{ Perception dimension } \\
\hline $\begin{array}{l}\text { Sympathetic and reassuring when } \\
\text { problems arise }\end{array}$ & 3.6 & 3.8 & 4.11 & 3.65 & 3.36 & 3.07 & 4.02 & 4.27 \\
\hline Trust officials at seaports & 3.31 & 3.66 & 3.76 & 3.05 & 3.47 & 3.39 & 3.6 & 3.9 \\
\hline $\begin{array}{l}\text { Feel safe in my transactions with } \\
\text { officials at seaports }\end{array}$ & 3.7 & 4 & 4.15 & 2.86 & 3.66 & 3.49 & 3.91 & 4.29 \\
\hline Seaports officials are polite & 3.61 & 3.75 & 3.77 & 3.62 & 3.11 & 3.46 & 3.94 & 3.99 \\
\hline $\begin{array}{l}\text { Officials get adequate support } \\
\text { from management }\end{array}$ & 3.83 & 3.77 & 3.95 & 2.63 & 3.24 & 3.14 & 4.14 & 4.12 \\
\hline Perception scores & 3.61 & 3.8 & 3.95 & 3.16 & 3.37 & 3.31 & 3.92 & 4.11 \\
\hline \multicolumn{9}{|l|}{ Gap scores } \\
\hline $\begin{array}{l}\text { Sympathetic and reassuring when } \\
\text { problems arise }\end{array}$ & -1.37 & -1.17 & -0.88 & -1.35 & -1.64 & -1.89 & -0.98 & -0.65 \\
\hline Trust officials at seaports & -1.68 & -1.32 & -1.08 & -1.93 & -1.53 & -1.58 & -1.38 & -1.05 \\
\hline $\begin{array}{l}\text { Feel safe in my transactions with } \\
\text { officials at seaports }\end{array}$ & -1.27 & -0.95 & -0.7 & -2.14 & -1.34 & -1.48 & -1.07 & -0.64 \\
\hline Seaports officials are polite & -1.39 & -1.22 & -0.94 & -1.38 & -1.86 & -1.51 & -1.01 & -0.98 \\
\hline $\begin{array}{l}\text { Officials get adequate support from } \\
\text { management }\end{array}$ & -1.16 & -1.2 & -1 & -2.37 & -1.7 & -1.82 & -0.78 & -0.83 \\
\hline Gap scores & -1.37 & -1.17 & -0.92 & -1.83 & -1.61 & -1.66 & -1.04 & -0.83 \\
\hline
\end{tabular}

Source: Authors

expectation and perception scores for all other questions under the assurance dimension are reported in Table 7.

With reference to the average gap scores under the assurance dimension, negative gap scores of -1.37 for ENLC, -1.17 for ABT, -0.92 for APMT, -1.83 for FSLT, -1.61 for TICT, -1.66 for PCHS, -1.04 for JPS and -0.83 for PTML are obtained. Thus, in all, PTML ranks highest under the assurance dimension, followed by APMT, JPS, ABT, ENLC, TICT, PCHS and FSLT respectively.

Further, with reference to the empathy dimension (Table 8) concerning giving individual attention to customers, we obtain negative gap scores of - 1.49 for ENLC, -1.42 for ABT, -1.28 for APMT, -1.68 for FSLT, -1.7 for TICT, -1.51 for PCHS, -1.25 for JPS and -0.97 for PTML. Thus, when we consider whether seaport officials give individual attention to customers, PTML ranks highest, followed by JPS, APMT, ABT, ENLC, PCHS, FSLT and TICT respectively. Results concerning the remaining questions under the same dimension are reported in Table 8.

Regarding the average gap scores, it is evident that all the expectation scores are above the perception scores resulting in negative gap scores of -1.25 for ENLC, -1.15 for ABT, 
Table 8 Service quality expectation and perception average scores for empathy

\begin{tabular}{|c|c|c|c|c|c|c|c|c|}
\hline Service quality questions & ENLC & $\mathrm{ABT}$ & APMT & FSLT & $\mathrm{TICT}$ & PCHS & JPS & $\overline{\text { PTML }}$ \\
\hline \multicolumn{9}{|l|}{ Expectation dimension } \\
\hline Individual attention to customers & 5 & 4.98 & 4.99 & 5 & 4.99 & 4.97 & 4.97 & 4.97 \\
\hline Personal attention & 5 & 4.98 & 4.87 & 5 & 4.94 & 4.99 & 4.97 & 4.99 \\
\hline Officials know the needs of customers & 5 & 4.98 & 4.96 & 5 & 4.97 & 4.99 & 4.97 & 4.99 \\
\hline $\begin{array}{l}\text { Officials have customers best interests } \\
\text { at heart }\end{array}$ & 4.97 & 4.98 & 4.75 & 4.98 & 4.89 & 4.89 & 4.95 & 4.93 \\
\hline Operate at hours convenient to customers & 4.97 & 4.98 & 4.91 & 4.98 & 4.99 & 4.96 & 4.97 & 4.95 \\
\hline Expectation scores & 4.99 & 4.98 & 4.9 & 4.99 & 4.96 & 4.96 & 4.97 & 4.97 \\
\hline \multicolumn{9}{|l|}{ Perception dimension } \\
\hline Individual attention to customers & 3.51 & 3.56 & 3.71 & 3.32 & 3.29 & 3.46 & 3.72 & 4 \\
\hline Personal attention & 3.4 & 3.39 & 3.2 & 3.45 & 3.23 & 3.19 & 3.92 & 3.85 \\
\hline Officials know the needs of customers & 4.3 & 4.13 & 4.13 & 3.86 & 4.21 & 4.03 & 4.23 & 4.52 \\
\hline $\begin{array}{l}\text { Officials have customers best interests } \\
\text { at heart }\end{array}$ & 3.51 & 3.85 & 3.89 & 3.02 & 3.49 & 3.24 & 3.95 & 4.14 \\
\hline Operate at hours convenient to customers & 3.99 & 4.23 & 4.37 & 3.57 & 4.47 & 4.33 & 3.83 & 4.64 \\
\hline Perception scores & 3.74 & 3.83 & 3.86 & 3.44 & 3.74 & 3.65 & 3.93 & 4.23 \\
\hline \multicolumn{9}{|l|}{ Gap scores } \\
\hline Individual attention to customers & -1.49 & -1.42 & -1.28 & -1.68 & -1.7 & -1.51 & -1.25 & -0.97 \\
\hline Personal attention & -1.6 & -1.59 & -1.67 & -1.55 & -1.71 & -1.8 & -1.05 & -1.14 \\
\hline Officials know the needs of customers & -0.7 & -0.85 & -0.83 & -1.14 & -0.76 & -0.96 & -0.74 & -0.47 \\
\hline $\begin{array}{l}\text { Officials have customers best interests } \\
\text { at heart }\end{array}$ & -1.46 & -1.13 & -0.86 & -1.96 & -1.4 & -1.65 & -1 & -0.79 \\
\hline Operate at hours convenient to customers & -0.98 & -0.75 & -0.54 & -1.41 & -0.52 & -0.63 & -1.14 & -0.31 \\
\hline Gap scores & -1.25 & -1.15 & -1.04 & -1.55 & -1.22 & -1.31 & -1.04 & -0.74 \\
\hline
\end{tabular}

Source: Authors

- 1.04 for APMT, -1.55 for FSLT, -1.22 for TICT, -1.31 for PCHS, -1.04 for JPS and 0.74 for PTML. Thus, PTML ranks highest under the empathy dimension. This is followed by APMT and JPS, ABT, TICT, ENLC, PCHS and FSLT respectively. Ugboma et al. (2004) report similar findings for the Lagos and Port Harcourt seaports.

Concerning the transparency dimension (Table 9) regarding the transparency of custom/trade procedures, documentation, laws and processes, negative gap scores of -0.56 for ENLC, -0.61 for ABT, -0.67 for APMT, -0.89 for FSLT, -0.36 for TICT, -0.87 for PCHS, -0.86 for JPS and -0.48 for PTML are obtained. Thus, with regard to the transparency of custom/trade procedures, documentation, laws and processes, TICT ranks highest, followed by PTML, ENLC, ABT, APMT, JPS, PCHS and FSLT in that order. The expectation, perception and gap scores for all other questions under the transparency dimension are reported in Table 9.

With respect to the average gap scores for expectation and perception under the transparency dimension, we observe that, negative gap scores of -1.15 for ENLC, -0.97 for ABT, -0.65 for APMT, -1.4 for FSLT, -1.16 for TICT, -1.4 for PCHS, -1.25 for JPS and -0.85 for PTML are obtained. In all, APMT ranks highest under the transparency dimension, followed by PTML, ABT, ENLC, TICT, JPS, and FSLT and PCHS respectively.

From the results in Tables 4, 5, 6, 7, 8 and 9 it can be observed that while PTML has the highest service quality in terms of tangibility, reliability, responsiveness, assurance and empathy dimensions, APMT performs best in terms of the transparency dimension. 
Table 9 Service quality expectation and perception average scores for transparency

\begin{tabular}{|c|c|c|c|c|c|c|c|c|}
\hline Service quality questions & ENLC & ABT & APMT & FSLT & TICT & PCHS & JPS & PTML \\
\hline \multicolumn{9}{|l|}{ Expectation dimension } \\
\hline $\begin{array}{l}\text { Transparency with regard to custom/trade } \\
\text { procedures, documentation, laws and } \\
\text { processes }\end{array}$ & 5 & 4.97 & 4.55 & 5 & 5 & 5 & 5 & 4.9 \\
\hline Equity in customs law enforcement & 5 & 4.98 & 4.77 & 5 & 5 & 4.93 & 5 & 4.93 \\
\hline Deliberately extort money from customers & 4.84 & 4.97 & 4.67 & 5 & 4.9 & 4.99 & 4.69 & 4.7 \\
\hline $\begin{array}{l}\text { Willing to give extra money to influence } \\
\text { seaports officials }\end{array}$ & 4.76 & 5 & 3.96 & 4.83 & 4.9 & 4.93 & 4.28 & 4.75 \\
\hline Trade related information are readily available & 5 & 5 & 4.69 & 5 & 4.99 & 4.97 & 4.98 & 4.99 \\
\hline Expectation scores & 4.92 & 4.98 & 4.53 & 4.97 & 4.96 & 4.96 & 4.79 & 4.85 \\
\hline \multicolumn{9}{|l|}{ Perception dimension } \\
\hline $\begin{array}{l}\text { Transparency with regard to custom/trade } \\
\text { procedures, documentation, laws and } \\
\text { processes }\end{array}$ & 4.44 & 4.36 & 3.88 & 4.11 & 4.64 & 4.13 & 4.14 & 4.42 \\
\hline Equity in customs law enforcement & 4 & 4.31 & 4.01 & 3.75 & 4.26 & 4.04 & 3.82 & 4.4 \\
\hline Deliberately extort money from customers & 3.13 & 4.11 & 3.84 & 3.11 & 3.1 & 2.87 & 3.18 & 3.78 \\
\hline $\begin{array}{l}\text { Willing to give extra money to influence } \\
\text { seaports officials }\end{array}$ & 2.67 & 2.87 & 3.49 & 2.58 & 2.67 & 2.39 & 2.23 & 2.82 \\
\hline Trade related information are readily available & 4.63 & 4.44 & 4.16 & 4.26 & 4.34 & 4.41 & 4.34 & 4.6 \\
\hline Perception scores & 3.77 & 4.02 & 3.88 & 3.56 & 3.8 & 3.57 & 3.54 & 4 \\
\hline \multicolumn{9}{|l|}{ Gap scores } \\
\hline $\begin{array}{l}\text { Transparency with regard to custom/trade } \\
\text { procedures, documentation, laws and } \\
\text { processes }\end{array}$ & -0.56 & -0.61 & -0.67 & -0.89 & -0.36 & -0.87 & -0.86 & -0.48 \\
\hline Equity in customs law enforcement & -1 & -0.67 & -0.76 & -1.25 & -0.74 & -0.89 & -1.18 & -0.53 \\
\hline Deliberately extort money from customers & -1.71 & -0.86 & -0.83 & -1.89 & -1.8 & -2.12 & -1.51 & -0.92 \\
\hline $\begin{array}{l}\text { Willing to give extra money to influence } \\
\text { seaports officials }\end{array}$ & -2.09 & -2.13 & -0.47 & -2.25 & -2.23 & -2.54 & -2.05 & -1.93 \\
\hline Trade related information are readily available & -0.37 & -0.56 & -0.53 & -0.74 & -0.65 & -0.56 & -0.64 & -0.39 \\
\hline Gap scores & -1.15 & -0.97 & -0.65 & -1.4 & -1.16 & -1.4 & -1.25 & -0.85 \\
\hline
\end{tabular}

Source: Authors

Analysis of gap scores across service quality dimensions and terminals

We present in Table 10, the average gap scores of each service quality dimension and the overall service quality for each terminal. With reference to the service quality dimensions, the gap scores are generated from the averages of those gained for items/questions under each dimension while that of total service quality are the averages for each dimension. This is done to give a better picture on quality of service offered as well as ranking the overall

Table 10 Average gap scores across service quality dimensions and terminals

\begin{tabular}{llllllllll}
\hline Service quality dimensions & ENLC & ABT & APMT & FSLT & TICT & PCHS & JPS & PTML & Overall average \\
\hline Tangibility & -1.29 & -1.11 & -0.92 & -2.21 & -1.01 & -1.23 & -1.07 & -0.74 & $\mathbf{- 1 . 2 0}$ \\
Reliability & -1.18 & -1.15 & -1.03 & -2.00 & -1.65 & -1.71 & -0.81 & -0.78 & $\mathbf{- 1 . 2 9}$ \\
Responsiveness & -1.42 & -1.08 & -0.86 & -1.79 & -1.83 & -1.73 & -1.02 & -0.79 & $\mathbf{- 1 . 3 2}$ \\
Assurance & -1.37 & -1.17 & -0.92 & -1.83 & -1.61 & -1.66 & -1.04 & -0.83 & $\mathbf{- 1 . 3 0}$ \\
Empathy & -1.25 & -1.15 & -1.04 & -1.55 & -1.22 & -1.31 & -1.04 & -0.74 & $\mathbf{- 1 . 1 6}$ \\
Transparency & -1.15 & -0.97 & -0.65 & -1.4 & -1.16 & -1.40 & -1.25 & -0.85 & $\mathbf{- 1 . 1 0}$ \\
Overall average & $\mathbf{- 1 . 2 8}$ & $\mathbf{- 1 . 1 1}$ & $\mathbf{- 0 . 9 0}$ & $\mathbf{- 1 . 8 0}$ & $\mathbf{- 1 . 4 1}$ & $\mathbf{- 1 . 5 1}$ & $\mathbf{- 1 . 0 4}$ & $\mathbf{- 0 . 7 9}$ & \\
\hline
\end{tabular}


performances of the selected terminals. Generally, for all the terminals, all service quality dimensions have negative gap scores. This implies that services rendered at these terminals are below the quality expected by customers. This finding is not surprising since customers' expectations are far above their perceptions about services provided at these terminals.

In Table 10, with reference to the overall service quality per dimension for the selected terminals, transparency has the highest service quality $(-1.1)$ followed by empathy $(-1.16)$, tangibility $(-1.2)$, reliability $(-1.29)$, assurance $(-1.3)$ and responsiveness $(-1.32)$ in that order. Thus, whilst the selected terminals are relatively performing with regard to transparency, empathy and tangibility dimensions, they lag behind in their performance in responsiveness, assurance and reliability. This implies that terminal authorities need to work harder on responsiveness, assurance and reliability dimensions of service quality in order to enhance efficiency and hence improve socio-economic outcomes. Moreover, considering the overall service quality in relation to the selected terminals, PTML emerges as the best performer $(-0.79)$, followed by APMT $(-0.90)$, JPS $(-1.04)$, ABT $(-1.11)$, ENLC $(-1.28)$, TICT $(-1.41)$, PCHS $(-1.51)$ and FSLT $(-1.80)$ respectively. Thus, services offered at PTML outperform those of the other terminals with FSLT being the least performer. This calls for urgent measures at the least performing terminals by their authorities.

In addition, concerning intra terminal performance per service quality dimension, we find that transparency (responsiveness) is the best (worst) service quality dimension for ENLC whilst for ABT, transparency (assurance) is the best (worst) service quality dimension. Concerning APMT, transparency (empathy) is the best (worst) service quality dimension whilst for FSLT, transparency (tangibility) is the best (worst) service quality dimension. Regarding TICT, tangibility (responsiveness) is the best (worst) service quality dimension whilst for PCHS, tangibility (responsiveness) is the best (worst) service quality dimension. With reference to JPS, reliability (transparency) is the best (worst) service quality dimension whilst for PTML, tangibility and empathy (transparency) are (is) the best (worst) service quality dimension. Hence by showing the dimension each terminal performs better and worse, it is highlighted to stakeholders on what factors to look up to in the quest to enhance service quality at these terminals. The low service quality of responsiveness for ENLC, TICT and PCHS, empathy for APMT, assurance for ABT, tangibility for FSLT and transparency for JPS and PTML for example shows the need for these terminals to focus on enhancing services linked to questions under these dimensions.

\section{Test of reliability}

Haven presented the findings related to service quality performance of the selected terminals in Nigeria, it is essential to note that the statistical strength and adequacy of the findings are based crucially on the internal consistency and hence reliability of the instrument and variables used. The reliability test results (see Appendix C) for all the attributes and the overall reliability results (see Table 11) indicate that the instrument employed for the study is highly reliable.

Table 11 Reliability test results

\begin{tabular}{lccc}
\hline Number of items & Minimum alpha value & Maximum alpha value & Overall alpha value \\
\hline 56 & 0.89 & 0.90 & 0.90 \\
\hline Source: Authors & &
\end{tabular}


Key challenges involved in exports and imports at selected terminals

In this sub-section, we highlight at the individual terminal levels the challenges that customers face in exports and imports of goods. These challenges are based on port users' responses to the question pertaining to problems they encounter when importing and exporting.

For PCHS, the challenges reported by customers are undue delays in clearing of invoices, bad communication network, high cost of services, over congestion and bad road network leading to the terminal. For ENLC, they report traffic congestion around the terminal and loading delays as the main challenges. Concerning FSLT, poor service delivery, old-fashioned equipment at the terminal, cumbersome documentation procedures and manual operations instead of using machinery are the main challenges reported whilst with reference to APMT, poor internet network, problem of location and parking of cargo, high cost of import duties, change of arrival date of containers at the terminal and cumbersome customs procedures are the main challenges reported.

With reference to PTML, congestion, delays by officials at the terminal, poor road network leading to the terminal and poor internet network are the main challenges reported whilst for ABT, the main challenges reported are poor internet network, delays in custom clearance and inadequate warehousing services at the terminal. Regarding JPS, the main challenges reported are difficulty in moving cargo out of the terminal and poor internet network whilst for TICT the main challenges reported are congestion at the terminal resulting in undue delays, workload exceeding terminal capacity, cumbersome processes and bad entry and exit routes.

\section{Conclusions and policy suggestions}

In this paper, we do a terminal level analysis of service quality across eight Nigerian seaport terminals- ENCL Consortium Ltd., Apapa Bulk Terminal (ABT), AP Moller Terminal (APMT), Five Star Logistics Ltd. (FSLT), Tincan Island Container Terminal (TICT), Ports and Cargo Handling Service Ltd. (PCHS), Josepdam Port Services (JPS) and Ports and Terminal Multi-Service Ltd. (PTML). Data is sourced with the aid of questionnaires to sample 549 users or customers of the selected terminals, while the gap score technique of the SERVQUAL model is the empirical estimation strategy used. This paper contributes immensely to knowledge and policy discussions by being the first to the best of our knowledge to provide a terminal level analysis of service quality of selected seaports terminals in Nigeria. Doing so reveals important areas to focus on in the quest to improve service quality among Nigerian seaports and Africa in general. From the results, it is evident that, all the selected terminals have low service quality in terms of reliability, tangibility, assurance, empathy, transparency and responsiveness. In addition, concerning the average gap score per service quality dimension for all the selected terminals, transparency has the best service quality (least gap score) whiles responsiveness has the least service quality (highest gap score).

However, in terms of service quality among the selected terminals, PTML emerges as the best performer, followed by APMT, JPS, ABT, ENLC, TICT, PCHS and FSLC in that order. Also, the study finds that responsiveness is the least service quality dimension for ENLC, TICT and PCHS, empathy is the least service quality dimension for APMT, assurance for ABT, tangibility for FSLT and transparency for JPS and PTML. The study therefore highlights the specific dimensions that need relatively more attention for specific terminals. 
This study has some important policy implications for the selected terminals. Concerning ENLC, the study reveals responsiveness and assurance as the least rated dimensions and hence attention should be given to offering prompt services, willingness to help customers as well as telling customers when services would be performed. Also, efforts should be made toward being sympathetic and reassuring when problems arise and also improving trust and politeness of terminal officials.

For ABT, assurance, empathy and reliability are the least rated service quality dimensions. This implies that for ABT, being sympathetic and reassuring when problems arise, improving trust and politeness of terminal officials, having customer's best interest at heart, knowing the needs of customers, giving individual attention to customers, operating at hours convenient to customers, rendering fast and efficient services, keeping records accurately and honouring promises on time are some of the factors that need urgent attention in order to enhance service quality.

Regarding APMT, empathy and reliability are rated as the least dimensions of service quality and hence operating at hours convenient to customers, having customer's best interests at heart, knowing the needs of customers, giving individual attention to customers, keeping records accurately, honouring promises on time and rendering fast and efficient services are some of the factors that need urgent attention in order to enhance service quality at APMT.

With reference to FSLT, tangibility and reliability are the least rated service quality dimensions. Therefore, in order to improve service quality at FSLT, attention should be given to initiatives that will ensure physical facilities are appealing, equipments are up-to-date and in line with services provided, ensuring fast and efficient services, keeping records accurately and honouring promises on time.

Regarding TICT and PCHS, attention should be given to keeping records accurately, honouring promises on time and ensuring fast and efficient services. Also offering prompt services, willingness to help customers as well as telling customers when services would be performed should be targeted. This is because reliability and responsiveness are rated as the least dimensions of service quality in TICT and PCHS.

For JPS, ensuring transparency with regard to trade/custom procedures, laws and processes, equity in customs law enforcement and reducing the extortion of money from customers as well as ensuring equipment are up-to-date, physical facilities are appealing and in line with services provided should be instituted because transparency and tangibility are rated the least dimensions of service quality at JPS.

With reference to PTML, transparency and assurance are found the least rated service quality dimensions. Therefore, ensuring equity in customs law enforcement, transparency with regard to trade/custom procedures, laws and processes and avoiding the extortion of money from customers as well as being sympathetic and reassuring when problems arise, improving trust and politeness of terminal officials, are some of the measures that can be embarked upon to ensure enhanced service quality at PTML.

Overall, it is evident that among all the dimensions of service quality, responsiveness and assurance are the least rated in all the selected terminals. Therefore, terminal authorities in Nigeria need to take urgent steps toward addressing all issues pertaining to responsiveness and assurance dimensions of service quality. 
On the issue of limitation and direction for future research, the study uses eight selected terminals of Port of Apapa and Tincan Island Port in Nigeria hence limiting the generalisation of results to seaport terminals in other African countries. Given this limitation, the study suggests that future research could focus on seaport terminals in other African countries to validate the present findings.

\section{Appendix B}

B1 Bonferroni comparison of perception scores by terminal

\begin{tabular}{|c|c|c|c|c|c|c|c|}
\hline & ENLC & ABT & APMT & FSLT & $\mathrm{TICT}$ & PCHS & JPS \\
\hline \multirow[t]{2}{*}{ ABT } & 0.18 & & & & & & \\
\hline & 0.20 & & & & & & \\
\hline \multirow[t]{2}{*}{ APMT } & 0.25 & 0.07 & & & & & \\
\hline & 0.00 & 1.00 & & & & & \\
\hline \multirow[t]{2}{*}{ FSLT } & -0.49 & -0.68 & -0.74 & & & & \\
\hline & 0.00 & 0.00 & 0.00 & & & & \\
\hline \multirow[t]{2}{*}{ TICT } & -0.15 & -0.33 & -0.40 & 0.35 & & & \\
\hline & 0.70 & 0.00 & 0.00 & 0.00 & & & \\
\hline \multirow[t]{2}{*}{ PCHS } & -0.26 & -0.44 & -0.51 & 0.23 & -0.12 & & \\
\hline & 0.00 & 0.00 & 0.00 & 0.01 & 1.00 & & \\
\hline \multirow[t]{2}{*}{ JPS } & 0.19 & 0.005 & -0.06 & 0.68 & 0.33 & 0.45 & \\
\hline & 0.14 & 1.00 & 1.00 & 0.00 & 0.00 & 0.00 & \\
\hline \multirow[t]{2}{*}{ PTML } & 0.46 & 0.27 & 0.21 & 0.95 & 0.60 & 0.72 & 0.27 \\
\hline & 0.00 & 0.00 & 0.03 & 0.00 & 0.00 & 0.00 & 0.00 \\
\hline
\end{tabular}

For each terminal comparison, mean scores are in first row and $p$-values are in second row Source: Authors

B2 Bonferroni comparison of expectation scores by terminal

\begin{tabular}{|c|c|c|c|c|c|c|c|}
\hline & ENLC & $\mathrm{ABT}$ & APMT & FSLT & $\mathrm{TICT}$ & PCHS & JPS \\
\hline \multirow[t]{2}{*}{ ABT } & 0.02 & & & & & & \\
\hline & 1.00 & & & & & & \\
\hline \multirow[t]{2}{*}{ APMT } & -0.12 & -0.13 & & & & & \\
\hline & 0.00 & 0.00 & & & & & \\
\hline \multirow[t]{2}{*}{ FSLT } & 0.02 & 0.003 & 0.14 & & & & \\
\hline & 1.00 & 1.00 & 0.00 & & & & \\
\hline \multirow[t]{2}{*}{ TICT } & -0.002 & -0.02 & 0.11 & -0.02 & & & \\
\hline & 1.00 & 1.00 & 0.00 & 1.00 & & & \\
\hline \multirow[t]{2}{*}{ PCHS } & -0.02 & -0.04 & 0.09 & -0.05 & -0.02 & & \\
\hline & 1.00 & 0.93 & 0.00 & 0.50 & 1.00 & & \\
\hline \multirow[t]{2}{*}{ JPS } & -0.04 & -0.06 & 0.07 & -0.07 & -0.04 & -0.02 & \\
\hline & 0.72 & 0.05 & 0.00 & 0.02 & 0.88 & 1.00 & \\
\hline \multirow[t]{2}{*}{ PTML } & -0.02 & -0.04 & 0.09 & -0.04 & -0.02 & 0.0005 & 0.02 \\
\hline & 1.00 & 0.94 & 0.00 & 0.55 & 1.00 & 1.00 & 1.00 \\
\hline
\end{tabular}

For each terminal comparison, mean scores are in first row and $p$-values are in second row Source: Authors 


\section{Appendix C}

C1 Reliability test results (Expectation and perception)

\begin{tabular}{|c|c|c|}
\hline Item (Dimensional attribute) & $\begin{array}{l}\text { Average inter item } \\
\text { covariance }\end{array}$ & $\begin{array}{l}\text { Alpha } \\
\text { value }\end{array}$ \\
\hline \multicolumn{3}{|l|}{ Tangibility } \\
\hline Excellent service provider at seaports will have up-to-date equipment & 0.06 & 0.90 \\
\hline Service provider at this seaport has up-to-date equipment & 0.06 & 0.89 \\
\hline Physical facilities at excellent seaports will be visually appealing & 0.06 & 0.90 \\
\hline This seaport's physical facilities are visually appealing & 0.06 & 0.89 \\
\hline Staff at excellent seaports will be well-dressed and neat & 0.06 & 0.90 \\
\hline Staff at this seaport are well-dressed and neat & 0.06 & 0.89 \\
\hline $\begin{array}{l}\text { The appearance of physical facilities at excellent seaports will be in } \\
\text { line with the type of services provided }\end{array}$ & 0.06 & 0.90 \\
\hline $\begin{array}{l}\text { The appearance of physical facilities at this seaport is in line with the } \\
\text { type of services provided }\end{array}$ & 0.06 & 0.90 \\
\hline \multicolumn{3}{|l|}{ Reliability } \\
\hline $\begin{array}{l}\text { When officials at excellent seaports promise to do something by the } \\
\text { time given, they will do so }\end{array}$ & 0.06 & 0.90 \\
\hline $\begin{array}{l}\text { When officials at this seaport promise to do something by the time } \\
\text { given, they do so }\end{array}$ & 0.06 & 0.89 \\
\hline $\begin{array}{l}\text { When there is a problem, employees at excellent seaports will be } \\
\text { concerned and supportive }\end{array}$ & 0.06 & 0.90 \\
\hline $\begin{array}{l}\text { When there is a problem, employees at this seaport are concerned } \\
\text { and supportive }\end{array}$ & 0.06 & 0.89 \\
\hline Excellent service providers will be dependable & 0.06 & 0.90 \\
\hline Service providers at this seaport are dependable & 0.06 & 0.89 \\
\hline $\begin{array}{l}\text { Excellent seaports officials will provide fast and efficient services } \\
\text { as promised }\end{array}$ & 0.06 & 0.90 \\
\hline This seaport officials provide fast and efficient services as promised & 0.05 & 0.89 \\
\hline Excellent seaports will keep records accurately & 0.06 & 0.90 \\
\hline Records are kept accurately at this seaport & 0.06 & 0.89 \\
\hline \multicolumn{3}{|l|}{ Responsiveness } \\
\hline $\begin{array}{l}\text { Excellent seaports officials will tell customers exactly when services } \\
\text { will be performed }\end{array}$ & 0.06 & 0.90 \\
\hline $\begin{array}{l}\text { This seaport officials do tell customers exactly when services will } \\
\text { be performed }\end{array}$ & 0.06 & 0.89 \\
\hline I will receive prompt services from excellent seaports officials & 0.06 & 0.90 \\
\hline I do receive prompt services from this seaport officials & 0.05 & 0.89 \\
\hline Excellent seaports officials will be willing to help customers & 0.06 & 0.90 \\
\hline This seaport officials are willing to help customers & 0.06 & 0.89 \\
\hline $\begin{array}{l}\text { Excellent seaports officials will be too busy to respond to customers' } \\
\text { request promptly }\end{array}$ & 0.06 & 0.90 \\
\hline $\begin{array}{l}\text { This seaport officials are too busy to respond to customers' request } \\
\text { promptly }\end{array}$ & 0.06 & 0.89 \\
\hline \multicolumn{3}{|l|}{ Assurance } \\
\hline $\begin{array}{l}\text { Excellent seaports officials will be sympathetic and reassuring when } \\
\text { problems arise }\end{array}$ & 0.06 & 0.90 \\
\hline This seaport officials are sympathetic and reassuring when problems arise & 0.06 & 0.89 \\
\hline I will trust officials at excellent seaports & 0.06 & 0.90 \\
\hline I trust officials at this seaport & 0.06 & 0.89 \\
\hline I will feel safe in my transactions with officials at excellent seaports & 0.06 & 0.90 \\
\hline
\end{tabular}


C1 Reliability test results (Expectation and perception) (Continued)

\begin{tabular}{|c|c|c|}
\hline Item (Dimensional attribute) & $\begin{array}{l}\text { Average inter item } \\
\text { covariance }\end{array}$ & $\begin{array}{l}\text { Alpha } \\
\text { value }\end{array}$ \\
\hline I feel safe in my transactions with officials at this seaport & 0.06 & 0.89 \\
\hline Excellent seaports officials are polite & 0.06 & 0.90 \\
\hline This seaport officials are polite & 0.06 & 0.89 \\
\hline $\begin{array}{l}\text { Excellent seaports officials will get adequate support from management } \\
\text { to do their jobs well }\end{array}$ & 0.06 & 0.90 \\
\hline $\begin{array}{l}\text { This seaport officials get adequate support from management to do } \\
\text { their jobs well }\end{array}$ & 0.06 & 0.89 \\
\hline \multicolumn{3}{|l|}{ Empathy } \\
\hline Excellent seaports officials will give individual attention to customers & 0.06 & 0.90 \\
\hline This seaport officials do give individual attention to customers & 0.06 & 0.89 \\
\hline Excellent seaports officials will give personal attention & 0.06 & 0.90 \\
\hline This Seaport officials do give personal attention & 0.06 & 0.89 \\
\hline Excellent seaports officials will know the needs of customers & 0.06 & 0.90 \\
\hline This seaport officials do know the needs of customers & 0.06 & 0.90 \\
\hline Excellent seaports officials will have customers best interests at heart & 0.06 & 0.90 \\
\hline This seaport officials do have customers best interests at heart & 0.06 & 0.89 \\
\hline Excellent seaports officials will operate at hours convenient to all customers & 0.06 & 0.90 \\
\hline This seaport officials do operate at hours convenient to all customers & 0.06 & 0.90 \\
\hline \multicolumn{3}{|l|}{ Transparency } \\
\hline $\begin{array}{l}\text { Excellent seaports officials will ensure transparency with regard to } \\
\text { custom/trade procedures, documentation, laws and processes }\end{array}$ & 0.06 & 0.90 \\
\hline $\begin{array}{l}\text { This seaport officials ensure transparency with regard to custom/trade } \\
\text { procedures, documentation, laws and processes }\end{array}$ & 0.06 & 0.90 \\
\hline Excellent seaports officials will ensure equity in customs law enforcement & 0.06 & 0.90 \\
\hline This seaport officials ensure equity in customs law enforcement & 0.06 & 0.90 \\
\hline Excellent seaports officials will deliberately extort money from customers & 0.06 & 0.90 \\
\hline This seaport officials deliberately extort money from customers & 0.06 & 0.90 \\
\hline $\begin{array}{l}\text { Traders will be willing to give extra money to influence excellent } \\
\text { seaports officials }\end{array}$ & 0.06 & 0.90 \\
\hline Traders wilfully give extra money to influence this seaport officials & 0.06 & 0.90 \\
\hline Trade related information will be readily available at excellent seaports & 0.06 & 0.90 \\
\hline Trade related information are readily available at this seaport & 0.06 & 0.90 \\
\hline Test scale & 0.06 & 0.90 \\
\hline
\end{tabular}

Source: Authors

\section{Supplementary information}

Supplementary information accompanies this paper at https://doi.org/10.1186/s41072-020-00069-9.

Additional file 1. Appendix A

\section{Abbreviations}

ABT: Apapa Bulk Terminal; AfDB: African Development Bank; APMT: AP Moller Terminal; ENLC: ENCL Consortium Ltd: FSLT: Five Star Logistics Ltd.; IPA: Importance-Performance Analysis; JPS: Josepdam Port Services; PCHS: Ports and Cargo Handling Service Ltd.; PTML: Ports and Terminal Multi-Service Ltd.; TICT: Tincan Island Container Terminal; TOPSIS: Similarity to Ideal Solution

\section{Acknowledgements}

We would like to thank all enumerators who aided in collection of data for this study. All remaining errors are those of the authors. 
Authors' contributions

All authors contributed equally to this manuscript. The authors read and approved the final manuscript.

\section{Funding}

This work was supported by Volkswagen (VW) Foundation within its Postdoctoral Fellowship Program in sub-Saharan Africa [Grant number: 94665].

\section{Availability of data and materials}

The datasets used for the analysis are available from the corresponding author on request.

\section{Competing interests}

The authors declare that they have no competing interests.

\section{Author details}

${ }^{1}$ Department of Economics, Kwame Nkrumah University of Science and Technology (KNUST), Private Mail Bag, Kumasi, Ghana. ${ }^{2}$ ECOWAS Commission, 101 Yakubu Gowon Crescent, Abuja, Nigeria. ${ }^{3}$ Department of Economics, Mangalore University, Mangalagangotri, Mangalore 574199, India. ${ }^{4}$ Institute of Health Researh, University of Health and Allied Sciences, Mangalagangotri, Ghana, Ho PMB 31, Ghana.

Received: 1 April 2020 Accepted: 15 June 2020

Published online: 07 October 2020

\section{References}

Abdourahamane AS (2015) Port efficiency underlies African competitiveness https://www.porttechnology.org/news/ portefficiency_underlies_african_competitiveness. Accessed 5 Oct 2017

African Development Bank's first Transport Forum (2015) Port efficiency underlies African competitiveness https://www. porttechnology.org/news/port_efficiency_underlies_african_competitiveness. Accessed 5 Oct 2017

African Ports Evolution (2016) Port evolution https://www.iru.org/what-we-do/networking/events/african-ports-evolution-2 016. Accessed 15 Oct 2017

Brady MK, Cronin JJ (2001) Some new thoughts on conceptualizing perceived service quality: A hierarchical approach. Journal of Marketing 65(3):34-49

Chang $\mathrm{CH}$, Thai W (2016) Do port security quality and service quality influence customer satisfaction and loyalty? Marit Pol Manag 43(6):720-736. https://doi.org/10.1080/03088839.2016.1151086

Chikere CA, Ibe CC, Stephens MS, Nze ON, Ukpere WI (2014) Motivating factors for cargo diversion from Nigerian ports to neighbouring ports. J Econs 5(1):77-86. https://doi.org/10.1080/09765239.2014.11884986

Cronbach LJ (1951) Coefficient alpha and the internal structure of tests. Psychomelrika 16(1):297-334

Dabholkar PA, Thorp DI, Rentz JO (1996) A measure of service quality for retail stores: scale development and validation. Acad Market Sci 24:3-16. https://doi.org/10.1007/BF02893933

Douglas S, Meijer A (2016) Transparency and public value-analyzing the transparency practices and value creation of public utilities. Int J Pub Admin 39(12):940-951. https://doi.org/10.1080/01900692.2015.1064133

Field A (2009) Discovering statistics using SPSS. Sage Publication Inc., London

Ghotbabadi AR, Baharun R, Feiz S (2012) A review of service quality models. In: Abstracts of the 2nd international conference on management. Holiday Villa Beach Resort \& spa, Langkawi Kedah 11-12 June 2012

Gronroos C (1982) Strategic Management and marketing in the service sector: Helsingfors: Swedish school of Economics and Business Administration

Grönroos C (1984) A service quality model and its marketing implications. Euro J Mark 18(4):36-44. https://doi.org/10.1108/ EUM0000000004784

Hemalatha S, Dumpala L, Balakrishna B (2018) Service quality evaluation and ranking of container terminal operators through hybrid multi-criteria decision-making methods. Asian J Ship Log 34(2):137-144. https://doi.org/10.1016/j.ajsl.2018.06.010

Hoekman B, Shepherd B (2015) Who profits from trade facilitation initiatives? Implications for African countries. J Afri Trade 2(1-2):51-70. https://doi.org/10.1016/j.joat.2015.08.001

Ismail I, Haron H, Ibrahim DN, Isa SM (2006) Service quality, client satisfaction and loyalty towards audit firms. Manag Audit J 21(7):738-756. https://doi.org/10.1108/02686900610680521

Joshi A (2013) Do they work? Assessing the impact of transparency and accountability initiatives in service delivery. Dev Policy Rev 31:29-48. https://doi.org/10.1111/dpr.12018

Kolanović I, Dundović C, Jugović A (2011) Customer-based port service quality model. Promet - Traf Trans 23(6):495-502. https://doi.org/10.7307/ptt.v23i6.184

Lee PT, Hu KC (2012) Evaluation of the service quality of container ports by importance-performance analysis. Int J Shipping Transport Logistics 4(3):197-211

Lu J, Gong X, Wang L (2011) An empirical study of container terminal's service attributes. J Serv Sci Manag 4(1):97-109. https://doi.org/10.4236/issm.2011.41013

Onyemechi C, Amanze AC, Igboanusi C, Sule A (2017) Port service quality study of Nigerian seaports. J Ship Ocean Engin 7: 59-64. https://doi.org/10.17265/2159-5879/2017.02.002

Parasuraman A, Zeithaml VA, Berry LL (1985) A conceptual model of service quality and its implications for future research. J Mark 49(4):41-50. https://doi.org/10.1177/002224298504900403

Parasuraman A, ZeithamI VA, Berry LL (1988) SERVQUAL: a multiple-item scale for measuring consumer perception. J Retail 64(1):12

Regasa Y (2016) Dry ports service quality in Ethiopia: the case of Modjo and Kaliti dry ports and terminals A-comparative study http://213.55.95.56/handle/123456789/2055. Accessed 15 Oct 2017

Sakyi D, Bonuedi I, Opoku EEO (2018) Trade facilitation and social welfare in Africa. J Afri Trade 5(1-2):35-53. https://doi.org/ 10.1016/j.joat.2018.08.001 
Sakyi D, Villaverde J, Maza A, Bonuedi I (2017) The effects of trade and trade facilitation on economic growth in Africa. Afri Dev Rev 29(2):350-361. https://doi.org/10.1111/1467-8268.12261

Sayareh J, Iranshahi S, Golfakhrabadi N (2016) Service quality evaluation and ranking of container terminal operators. The Asian J Ship Log 32(4):203-212. https://doi.org/10.1016/j.ajsl.2016.12.003

Stverkova H (2015) Using SERVQUAL: a framework for determining and prioritizing critical factors in delivering quality services for the mobile operator. Adv Econs and Bus 3(6):225-231. https://doi.org/10.13189/aeb.2015.030604

Suuroja M (2003) Service quality-main conceptualizations and critique. University of Tartu Economics and Business Working Paper 23

Thai W (2016) The impact of port service quality on customer satisfaction: the case of Singapore. Marit Econs Log 18(4):458475. https://doi.org/10.1057/mel.2015.19

Ugboma C, Ibe C, Ogwude IC (2004) Service quality measurements in ports of a developing economy: Nigerian ports survey. Manag Servi Qual: An Intern J 14(6):487-495. https://doi.org/10.1108/09604520410569829

Ugboma C, Ogwude IC, Ugboma O, Nnadi K (2007) Service quality and satisfaction measurements in Nigerian ports: an exploration. Marit Pol Manag 34(4):331-346. https://doi.org/10.1080/03088830701539073

Yeo GT, Thai W, Roh SY (2015) An analysis of port service quality and customer satisfaction: the case of Korean containe ports. The Asian J Ship Log 31(4):437-447. https://doi.org/10.1016/j.ajsl.2015.08.008

Zeithaml VA (1988) Consumer perceptions of price, quality, and value: a means-end model and synthesis of evidence. J Mark 52(3):2-22. https://doi.org/10.1177/002224298805200302

\section{Publisher's Note}

Springer Nature remains neutral with regard to jurisdictional claims in published maps and institutional affiliations.

Submit your manuscript to a SpringerOpen ${ }^{\circ}$ journal and benefit from:

- Convenient online submission

- Rigorous peer review

- Open access: articles freely available online

- High visibility within the field

- Retaining the copyright to your article

Submit your next manuscript at $\boldsymbol{\nabla}$ springeropen.com 